\title{
Making Sense and Making Self through a Pandemic: Religious Responses
}

\author{
Roberto Rizzo \\ \{roberto.rizzo@mail.com\} \\ University of Milan, Italy
}

\begin{abstract}
This paper investigates the challenges that the spread of the Covid-19 crisis has posed on the everyday practice of established religions and the responses that have been formulated therein. As a privileged site for the inquiry into notions of multinaturalism, religion has long been regarded as the domain par excellence in which ontological claims are made explicit and embodied, while at the same time articulating hunches about "ultimate things". By scanning through several ethnographic examples from different religious fields, I re-cast religious experience in the spotlight of the manner in which many communities understand and cope with a sanitary and social form of distress and how it relates to dynamics of both inclusivity and exclusivity in the wider society.
\end{abstract}

Keywords: Religions, Multinaturalism, Covid-19

\section{Introduction}

As much of the world retreated into self-isolation and quarantines as countermeasures for the spread of the novel Coronavirus pandemic, so did most of the places of worship in Italy, one of the first countries to experience mass consequences of the epidemic and the country in which I happen to find myself during most of the early months of the crisis. Churches, mosques and temples were obliged to cancel all of their in-presence celebrations and move all activities on digital platforms. Not without a brief round of controversies, most denominations complied and reported a good response on the side of their followers, while at the same time reflected on the implications of removing in-presence participation from the regular worship sessions [1].

Controversies were perhaps only marginal to religious domains not immediately concerned with bodily presence in a house of worship, such as the various strands of Buddhism. Early in March 2020, all the activities of the country's temples had already moved to online platforms, mostly Facebook and YouTube live streaming's, although larger and popular complexes like Pian dei Ciliegi [2] had organized a dedicated website with sorted lectures, links to online readings and a constantly evolving archive of the live streaming's carried out over the quarantine period. Smaller groups had switched instead to privately arranged Skype, Zoom or Facebook group video calls. Attending some of the activities of Pian dei Ciliegi, I had the chance to witness the change in everyday practice that issued from the transfer of the worship and meditation sessions from the physical temple to the virtual streaming. While most of the regular activities were not particularly impacted, at least in their configuration, by the physical change of scene, the wider context of sanitary and social distress against which this temporary switch occurred stirred a series of new contemplations that I would find paralleled in similar virtual gatherings with Indonesian Buddhist groups. 
Some of the concerns expressed by affiliates in both contexts were, perhaps predictably, how to conceive of and how to possibly counteract in religious terms the present pandemic. One of the major preoccupations was of an ethical kind, that is, the possible moral consequences of eradicating a virus. Could a virus be hurt? Would the consequences of killing a virus be tantamount to killing a living being and therefore inviting "bad" karmic reactions? Questions of this kind were not easy matters to grapple with for practitioners and specialists alike. On a couple of occasions, however, the Pian dei Ciliegi lay specialist (like in Indonesia, in Italy too Buddhist religious gatherings are oftentimes officiated by experienced lay practitioners instead of ordained monks) recommended as reading suggestions from the Buddhist canon, the Ratana sutta, a section of the Sutta Nipata, which the Theravada school traditionally ascribes to the Khuddaka Nikaya. The sutta recounts a discourse of the Buddha Gautama which reaffirms the basic tenets of Buddhism, the triple jewel of Buddha-Dhamma-Sangha, recognized, accepted and recited by all Buddhists worldwide. While this sutta enjoys a degree of popularity in the Sri Lanka stream of Theravadism [3], it was practically unknown, or at least unmentioned as a textual corpus, in the Italian context I had followed for quite some time. The reason why this sutta was brought up in the circumstances surrounding the pandemic-related questions was to be found in the tradition which assigns the historical context of this discourse to the then plagued city of Vesali. Torn by all sorts of natural catastrophes, the city was further lacerated by a pestilence that followed the immense devastation that left behind rotting corpses and ruins. The citizens of Vesali began to be delivered from the plague (interestingly enough, believed to be cast by "evil spirits") as the Buddha recited the jewel discourse.

The point of interest of this brief account that I would like to emphasize, and that connects to the examples given below, is not so much the specific content of the scripture or the exact teaching given in response to the ethical concerns entangled with viral matters. Rather, it is the more fundamental and basic observation that the Covid-19 crisis has provoked shifts, subtle and not, in the perception, epistemology and practice of given established religions, shifts that would have otherwise not occurred and that provide interpretations as well as ontological versions that are alternative or integrating to the dominant scientific paradigms through which pandemic discourses have been channeled. In this way, I argue, religion is re-cast to the frontline of interpretative and ontological pandemic realities of everyday religiosity that are of relevance for many of the world's religious fields.

\section{Pandemic, Religion and Multiple Ontologies}

The scene that I sketched in the previous paragraphs, the set of questions linked to viruses brought by the Buddhist practitioners and the recuperation of marginalized scriptural bodies, links back to two of the fundamental features of religious epistemology. Theodicy, the "question of evil" [4][5][6][7] is undoubtedly one of the two, as the perception of pandemic-related distress and the threat to public health is predominantly read as an evil -genetical occurrence, linked to higher powers in varying fashions. Another one, and most relevant for discussions on multinaturalism, is cosmology. A broad term, mobilized in the discipline to do quite different jobs [8][9], cosmology is concerned, in religious domains, with the continuum between the macro- and the microcosm, or how the nonhuman forces assumed by a given religious tradition relate to the tangible world of nature, things, animals and humans. By elaborating on and giving qualities and content to the statuses of things around us, cosmology is the closest and most explicit area in a religion's bulk of concepts and practices, to what one may term a religion's ontology [5]. 
Recovering notions of cosmology and ontology is just another possible entry door to approach Viveiros De Castro's seminal work on the notion of multinaturalism [10]. By paying close attention to Amerindian practices in respect to what a mainstream Brazilian perspective would deem "nature", De Castro elaborated on the age-old anthropological dichotomy between "nature" and "culture" showing that the boundary between the two was far from fixed or universal. That nature, as an objectified and inert domain, indifferent to the action of humans and therefore exploitable, was, in other words, multiple in the way it was more or less socialized into the same world (the same "perspective") as humans', with all the implications deriving from it.

The powerful idea of multinaturalism and the paradigm of perspectivism that issued from it was brought closer to the realm of religion by the monumental work of Descola [11][12][13]. For Descola, the idea of multinaturalism, that the outer poles of socialization might be set up differently in different cultural configurations, was not only an intercultural variable, but it occurred and shifted constantly also within the same society. As when dogs as a species are dismissed as stray animals at the fringes of urban environments, not unlike compost or industrial byproduct ("nature"), while being, in the same society (or even the same city) incorporated into family environments, given shelter, affectionate nicknames, sophisticated care and even inheritance - in other words fully socialized into the world of "culture". Descola called this coexistence of different configurations of humans versus the environment through the lens of culture "plurality of ontologies". The identity of what exists in the world, that is, varies crossculturally and even within the same society, depending on the actors and contexts at play.

Religion is immediately involved in Descola's work, as he sketched a double-dichotomic continuum of two ontological axes, external $\leftrightarrow$ internal and physicality $\leftrightarrow$ interiority. If religion is, in Descola's definition, the public figuration of a nonhuman power that is (or it is rendered) manifest in the physical world, then these two axes would provide a convenient grid on which to identify four possible "religious ontologies". The interplay between the human and the nonhuman, then, would return the possibility of an entirely materialistic vision that excludes any possibility of interior presence ("naturalism") as well as its opposite ("animism"). Likewise, the more or less interior presence of more or less human-like features on the external/internal axis would complete the set with the "analogist" and "totemist" form of religious ontology. The tension between these continuums might be wrapped up in a graph:

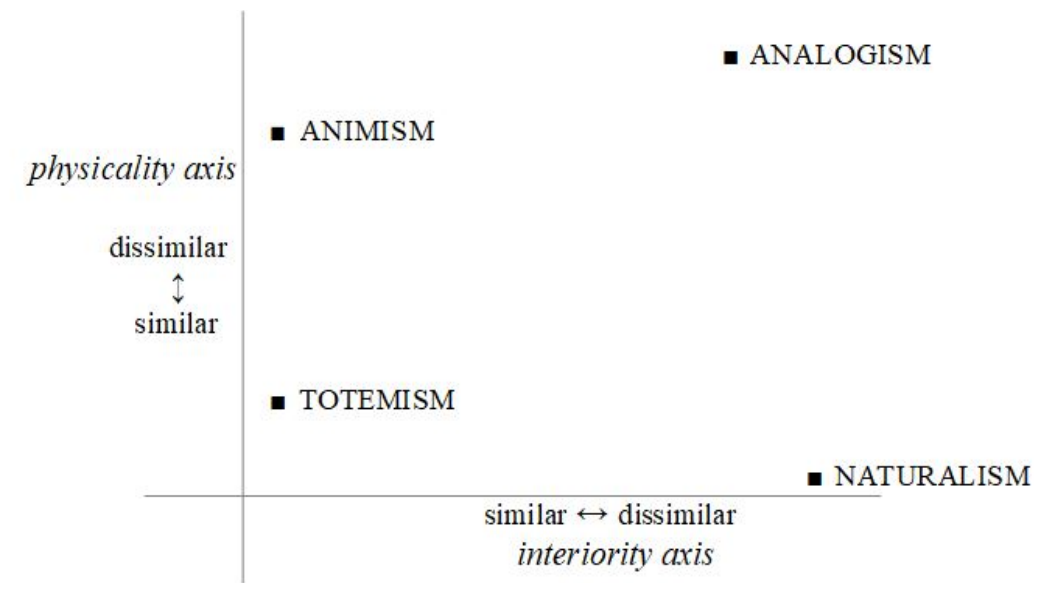

Fig. 1. Graph by author. 
The surge of viral talk that inevitably leaked into the realm of the religious, then, opened a question that wasn't yet readymade in most religious environments. Whether or not we choose to follow into Descola's and De Castro's trail, what ontology is a given religion to assign to a virus? How inclusive or exclusive need the "socialization poles" be staked in respect to the understandings of the nature/culture boundary and to the human/nonhuman relation? These questions are crucial in that they not only raise theological debates grounded on references to scriptures, doctrines and traditions, but they imply specific forms of action (or non-action, indifference) for specialists and lay practitioners alike. More broadly still, the preliminary questions one may put forward could be: how did established religion change or adapted their ontological framework in response to the Coronavirus-derived crisis? How did power configurations allow for dynamics of inclusion and exclusion? The numerous examples given, taken mostly from online accounts both academic and not, have elaborated on these very issues.

\section{Religious Responses}

\subsection{Viral Space}

Early on in the pandemic spread to the Central American states, concerns emerged over how to best counter it in the traditional healing techniques, performed invariably by the mambo priestess. A dedicated concoction (the ingredients of which have remained secret) was figured out as an antidote against the Covid-19 borne diseases by one of the voodoo leaders in Port au Prince [14]. As voodoo temples and the respective healing ceremonies have commonly provided a preferred go-to venue for the cure of all kinds of diseases, physical as well as psychological, so have they begun to be on-demand as the crisis surged in the country. The issue was, however, what space to use for isolating Covid-19 patients, as the occupation of the main ritual hall would have practically rendered the entire temple an environment for quarantine. In an unprecedented move, the voodoo deputy leader had allocated about one thousand initiation rooms in the country that could be temporarily converted to clinics for the treatment of Covid-19 patients by mamboes. The usage of a normally extremely secretive space for Covid-19 treatment aligned itself with the importance and gravity placed upon "invisible" forms of disease in the voodoo religious system and discord was expressed at Madagascar's president official statement in which he declared that a different plant-based cure was prompted for the treatment of Covid-19 patients instead of the traditional knowledge, practices and venues invoked by voodoo religious and healing systems.

\subsection{Viral Extent}

Ontological questions linked to the Coronavirus pandemic were perhaps most patent in the issues surrounding the reach and extent of the pandemic beyond the immediately human realm. The question was raised, among others, on the occasion of the "hungry ghost" festival in many diasporic Chinese communities [15]. Initiated as an ironical social media trend, linked to the tradition of burning paper items (mostly fake banknotes) on the occasion of the yearly festivity, doubts were eventually raised as for the possibility that ancestors would need a mask too and that therefore the burning of a mask on the ritual pyre would be an appreciated gesture, if not a 
moral obligation. Dead relatives of one or more generations back, that meant, were as pliable to the pandemic condition as their present flesh-and-bones heirs.

Issues of presence and extent were particularly explicit also in Hindu temples in Singapore [16]. While the concern of the Chinese community related to the possibility of viral vulnerability of ancestors - that is, of nonhuman entities that have been nonetheless regular human beings in the past - for Hindu priests the question was the exposure of gods, in the guise of statues, to the circulation of the virus. Several priests began wearing a mask when in the proximity of sacred statues, taking up the habit of spraying them with regular disinfectants on a daily basis, in continuity with the usual ritual treatments of godly statues - that is, waking them up, bathing and clothing them, putting them to sleep. The issue sparked an internal debate, recovering an ancient controversy within Saivism, of whether the idol-statue is to be regarded as only a symbolic referent of the deity or whether it is in itself a device through which the divinity diffuses.

\subsection{Viral Intercessions}

Nonhuman powers were called upon in different ways in other contexts. While the examples of the Singaporean Hindus and Chinese suggested an experiential continuum (or at least a possibility therein) of the pandemic condition of the human and the nonhuman agents, Orthodox Christians in Germany [17] and Indian Hindus [18] have adapted to the pandemic in quite different manners, without postulating or implying an extension of the viral effects beyond the realm of the immediately human. The community of Orthodox Christians, for instance, have recovered the cult of a nearly forgotten mediaeval saint, linked to a martyrdom that occurred under Roman rule in Southern Europe. The saint had so far nothing to do with pandemics beyond her canonized name: Saint Corona. Extremely few chapels and shrines of the saint exist in Europe but those, especially the one in Bavaria, Germany, have experienced an immediate surge in attendance by followers praying to the saint for the pandemic to cease. Orthodox leaders have eventually called for the official sanctioning of Saint Corona as protector of the Covid19 pandemic.

Similarly, Indian Hindus have coped with the theological as well as the practical issues imposed by the viral condition by elaborating on the vocabularies and codes available through the religious tradition, although in unusually creative ways. In an attempt to emphasize and exorcise the fight against Covid-19, a Durga shrine in Kolkata was altered to include doctors in the act of curing patients from the pandemic, while in Mumbai a CoronAsur (Asuras being traditionally considered "evil spirits") paper effigy was created, with the final intent to set it on fire. In this way, not only was the pandemic handed over to the usual realm of Durga Devi, but it made tangible an arguably very intangible disease, symbolically approachable and attackable.

\section{Conclusions}

In this paper, I discussed the links between the spread of the Covid-19 pandemic and the responses that various religious fields have given to issues of viral presence. Such responses have potentially moral and practical consequences and are invariably connected to questions of ontology and multinaturalism as devised by authors such as Viveiros De Castro and Philippe Descola. While the treatment of viruses in religious idioms is not a domain void of controversies and internal debate, the examples given are an attempt to show how, far from marginalizing 
them, the sanitary crisis has triggered novel approaches in established religious traditions and alternative ontological frameworks to the hegemony of scientific discourses. Like much work on Covid-19 derived configurations, research on the topic can so far be only preliminary and tentative and much room is left for further elaborations, in the light of the pandemic developments and the discourses around them.

\section{References}

[1] A. Fabris, "Messa sul web e in tv: la tecnologia ci aiuta, ma assistere non è partecipare," Toscanaoggi, 2020. [Online]. Available: https://www.toscanaoggi.it/Opinioni-Commenti/Messasul-web-e-in-tv-la-tecnologia-ci-aiuta-ma-assistere-non-e-partecipare.

[2] Piandeiciliegi, "Pian dei Ciliegi," Piandeiciliegi, 2020. [Online]. Available: https://www.piandeiciliegi.it/it/.

[3] J. Liyanaratne, Buddhism and traditional medicine in Sri Lanka, vol. 1. Kelaniya University Press Colombo, 1999.

[4] W. C. Olsen and T. J. Csordas, Engaging Evil: A Moral Anthropology, vol. 36. Berghahn Books, 2019.

[5] J. D. Eller, Introducing anthropology of religion: culture to the ultimate. Routledge, 2007.

[6] M. Lambek, "The anthropology of religion and the quarrel between poetry and philosophy," Curr. Anthropol., vol. 41, no. 3, pp. 309-320, 2000.

[7] U. Sharma, "Theodicy and the Doctrine of Karma," Man, vol. 8, no. 3, pp. 347-364, 1973.

[8] M. Douglas, "Natural symbols: explorations in cosmology. Barrie \& Rockliff." Cresset Press, London, 1970.

[9] E. Reichel, "Cosmology," Encycl. Relig. Nat., vol. 1, pp. 420-425, 2005.

[10] E. Viveiros de Castro, "Perspectival anthropology and the method of controlled equivocation," Tipití J. Soc. Anthropol. Lowl. South Am., vol. 2, no. 1, p. 1, 2004.

[11] P. Descola, The ecology of others. Prickly Paradigm Press, 2013.

[12] P. Descola and J. Lloyd, Beyond nature and culture, vol. 10. University of Chicago Press Chicago, 2013.

[13] P. Descola, "Presence, Attachment, Origin: Ontologies of 'Incarnates," A Companion to Anthropol. Relig., pp. 35-49, 2013.

[14] A. Paultre and R. Sanon, "Haiti voodoo leaders prepare temples for coronavirus sufferers," Reuters, 2020. [Online]. Available: https://www.reuters.com/article/us-health-coronavirus-haitivoodoo-featu/haiti-voodoo-leaders-prepare-temples-for-coronavirus-sufferersidUSKBN2300R9?fbclid=IwAR0uupcZBVcKqWLrnKfaQJcrB5Rrlgp9JX8N0G88Kw19oZVtlKboKBUNGw.

[15] E. Soh, "Prayers, Protocols and Pandemics, Part 1: Do My Ancestors Need Masks? The Impact of Coronavirus on the Seventh Lunar Month Festivities in Singapore," NUS, 2020. [Online]. Available: https://ari.nus.edu.sg/20331-46/.

[16] I. Arumugam, "Do the Gods Have COVID-19 Too?: Protecting Idols, Cherishing Deities," NUS, 2020. [Online]. Available: https://ari.nus.edu.sg/20331-44/.

[17] near G. Germany, "Germany: Bavarian St Corona Chapel sees visitor increase amid COVID-19 outbreak," Ruptly, 2020. [Online]. Available: https://www.ruptly.tv/en/videos/20200404-055Germany--Bavarian-St-Corona-Chapel-sees-visitor-increase-amid-COVID-19-outbreak.

[18] S. Kumari, "In Kolkata's Md Ali Park, Goddess Durga slays 'Coronasura', pays tribute to frontline warriors," Indian Express, 2020. [Online]. Available: https://indianexpress.com/article/lifestyle/art-and-culture/in-kolkatas-md-ali-park-goddessdurga-slays-coronasura-pays-tribute-to-frontline-warriors-6821381/. 